\title{
Waste and dust utilisation in shaft furnaces
}

\author{
D. Senk*, A. Babich* and H.W. Gudenau*
}

\begin{abstract}
Wastes and dusts from steel industry, non-ferrous metallurgy and other branches can be utilised e.g. in agglomeration processes (sintering, pelletising or briquetting) and by injection into shaft furnaces. This paper deals with the second way. Combustion and reduction behaviour of iron- and carbon-rich metallurgical dusts and sludges containing lead, zinc and alkali as well as other wastes with and without pulverised coal (PC) has been studied when injecting into shaft furnaces. Following shaft furnaces have been examined: blast furnace, cupola furnace, OxiCup furnace and imperial-smelting furnace. Investigations have been done at laboratory and industrial scale. Some dusts and wastes under certain conditions can be not only reused but can also improve combustion efficiency at the tuyeres as well as furnace performance and productivity.
\end{abstract}

Keywords Recycling. Injection. Shaft furnace. Dust. Sludge.

\section{Residuos y polvos para la utilizacion en hornos de cuba}

Lesumen residuos y polvos de filtro provenientes de la industria siderúrgica, de la obtención de
metales no ferrosos y de otras industrias, pueden ser utilizados, por ejemplo, en procesos
de aglomeración como sinterizado, peletizado o briqueteado. En su caso, estos pueden ser
inyectados en los hornos de cuba. Este artículo se enfoca a la inyección de estos materiales
en los hornos de cuba. El comportamiento de la combustión y reducción de los polvos ricos
en hierro y carbono y también lodos que contienen plomo, zinc y compuestos alcalínos y
otros residuos con o sin carbón pulverizado (CP) fue examinado, cuando se inyectaron en
hornos de cuba. Los siguientes hornos de cuba fueron examinados: Horno alto, cubilote,
OxiCup y horno de cuba Imperial Smelting. Las investigaciones se llevaron a cabo a escala
de laboratorio e industrial. Algunos residuos y polvos bajo ciertas condiciones, no sólo
pueden ser reciclados, sino también mejoran la eficiencia de combustión en las toberas, la
operación y productividad del horno.

Palabras clave Reciclado. Inyección. Horno de cuba. Polvo. Lodo.

\section{INTRODUCTION}

Recycling and waste minimisation are key words for sustainable development in a highly industrialised society. "Where there is muck, there is a money" ${ }^{\prime \prime}$.

Steel industry consumes 15-18 GJ energy per tonne of crude steel and discharges about $1,600 \mathrm{~kg}$ $\mathrm{CO}_{2} / \mathrm{t}$ of crude steel and a large amount of further gaseous, liquid and solid waste $\mathrm{e}^{[2 \text { and } 3]}$.

In German steel works 2,1 million tonnes dust and sludge are generated (in 2000) despite the impressive achievements in the reduction of dust emissions $^{[4]}$ (Fig. 1).

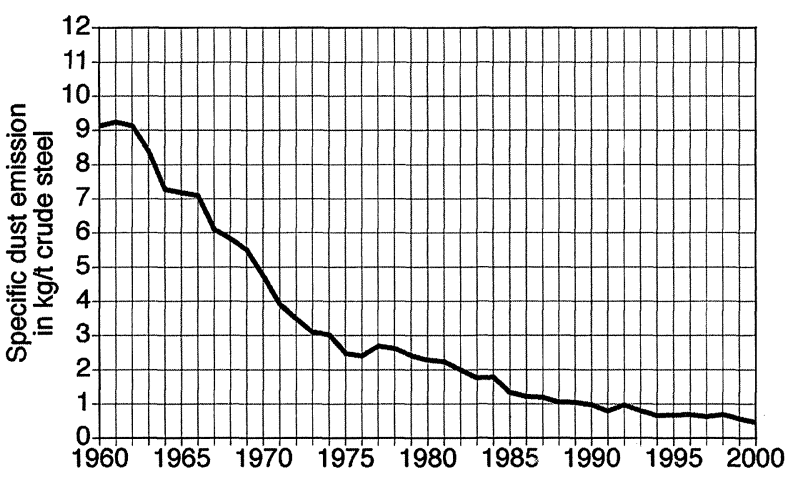

Figure 1. Specific dust emission in German steel industry ${ }^{[4]}$.

Figura 1. Emisión específica de polvos de la industria del acero alemana ${ }^{[4]}$. 
Waste and dust utilisation in shaft furnaces

Legislations in the EU countries require substantial and sustained environmental protection by means of saving raw material sources and avoidance of material going to landfill.

In ferrous and non-ferrous metallurgy new ways instead of dumping waste have to be found to protect the environment and due to increasing deposit costs. Nowadays there are various industrial technologies for recycling or recovery of metallurgical dusts and slurries that need however pre-treatment such as sintering or briquetting before re-introducing these materials into the melt.

Therefore direct reuse of dusts by injection into melting aggregates such as shaft furnaces, converters and electric arc furnaces is of advantage. This paper will discuss utilisation of metallurgical waste and dusts by injection into shaft furnaces such as blast furnace, cupola and imperial smelting furnace. A special energy optimised shaft furnace for waste utilisation - OxiCup - is also considered.

Combustion behaviour of municipal organic waste (e.g. plastics from the German waste plastics recycling system - "Duales System Deutschland") and waste from other branches (carbonaceous extracts from coal power station fly ash, shredder light fractions from the waste car recycling process etc.) with and without powder coal have been investigated at the Department of Ferrous Metallurgy of Aachen University in numerous studies $^{[5}$ and 6$]$, and is out of the scope of this work.

\section{INJECTION INTO BLAST FURNACE}

Injection of in-plant iron containing waste materials via the tuyeres into blast furnace $(B F)$ can provide coke and burden saving due to possible intensification of the PC combustion, decrease in hot metal silicon content, improvement of thermal state control in the hearth and replacement of a part of the primary burden materials.

Possibilities and conditions of recycling of mill scale and sludge, flue dust, iron ore fines and other iron containing waste materials from steel plant have been studied under the BF simulating conditions and results have been summarised in ${ }^{[5}$ and 7$]$.

Tests with BF flue dust in the mixture with pulverised coal using laboratory injection rig which simulates behaviour of injected solids within 10-20 $\mathrm{ms}$ in the tuyere and the oxidising part of the raceway showed rise in $\mathrm{PC}$ combustion degree by $20 \%$ when flue dust rate was $30 \%$ (Fig. 2) ${ }^{[8 \text { and 9] }}$. This result is only true for low volatile matter (ca. $11 \%)$ coal grades. Additional supply of oxygen

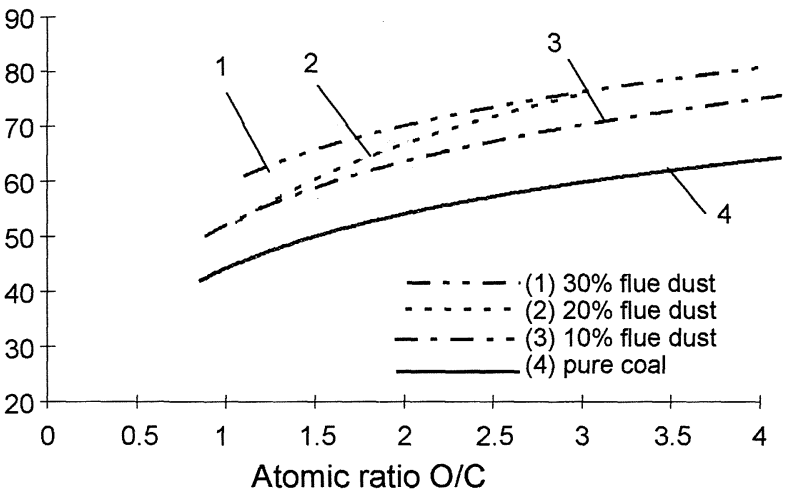

Figure 2. Combustion behaviour of flue dust - $\mathrm{PC}$ mixtures ${ }^{[7]}$.

Figura 2. Comportamiento de la combustión de las mezclas de polvo de tragante con $\mathrm{CP}^{[7]}$.

with flue dust does not affect the combustion degree of coal with high volatile matter content.

Industrial trials with flue dust-PC mixture injection were performed at blast furnace with hearth diameter of $7.2 \mathrm{~m}\left(\mathrm{~V}=1,033 \mathrm{~m}^{3}\right)$. A mixture of lean coal concentrate $\left(76.7 \% \mathrm{C}_{\mathrm{fix}}, 11.6 \% \mathrm{VM}\right.$, $8.9 \%$ ash) and flue dust $\left(39.6 \% \mathrm{Fe}_{\text {total }}, 12.5 \% \mathrm{C}\right.$, $13.7 \% \mathrm{CaO}, 3.8 \% \mathrm{MgO}, 0.48 \% \mathrm{Na}_{2} \mathrm{O}+\mathrm{K}_{2} \mathrm{O}$, $0.02 \% \mathrm{Zn}$ ) was used in ratio $85 / 15 \%$.

No negative effect on the blast furnace operation, mills and injection equipment was observed during the trials. Coke rate decreased by 0.5 and $3.6 \%$ in the $1^{\text {st }}$ and $2^{\text {nd }}$ test periods respectively (Table I). Furnace productivity did not change in the $1^{\text {st }}$ period and increased by $4 \%$ in the $2^{\text {nd }}$ period. Slag volume decreased during mixture injection. Slag basicity and pig iron quality were kept practically on the base level. Various techniques for the prevention of alkalis and zinc accumulation possible in the case of long operation with a high flue dust rate have been tested and discussed in ${ }^{[9]}$.

Recent trials with PC-flue dust mixture injection in an experimental $\mathrm{BF}$ and at BF-3 at the Luleå works have confirmed the advantages of this technology ${ }^{[10]}$.

\section{IMPERIAL SMELTING FURNACE}

Dusts containing harmful for blast furnace substances like compounds of zinc and lead can be recovered by injecting into the Imperial Smelting (IS) furnace via the tuyeres. An Imperial Smelting process is used for the production of zinc, mostly from primary zinc concentrates, in which the concentrates are heated, pelletised and reduced to zinc metal by coke in a shaft furnace ${ }^{[11]}$. The 
Table I. Parameters of BF operation with PC - flue dust mixture injection

Tabla I. Parámetros de la operación de inyección en el horno alto con mezclas de CP y polvo de tragante

\begin{tabular}{|c|c|c|c|c|c|}
\hline \multirow[t]{2}{*}{ Parameter } & & \multicolumn{2}{|c|}{ Period I } & \multicolumn{2}{|c|}{ Period II } \\
\hline & & Basis & Trial & Basis & Trial \\
\hline Sinter / pellets ratio, $\%$ & & $72.9 / 27.1$ & $69.9 / 30.1$ & $69.1 / 30.9$ & $58.6 / 41.4$ \\
\hline PC - flue dust, \% & & $100 / 0$ & $85 / 15$ & $100 / 0$ & $85 / 15$ \\
\hline Alkalis input, & total & 6.283 & 6.003 & 6.349 & 6.162 \\
\hline $\mathrm{kg} / \mathrm{tHM}$ & coke and CFM* & 1.151 & 1.142 & 1.176 & 1.235 \\
\hline \multirow[t]{4}{*}{ Hot metal analysis, \% } & $\mathrm{Si}$ & 0.89 & 0.76 & 0.84 & 0.92 \\
\hline & $\mathrm{S}$ & 0.032 & 0.032 & 0.027 & 0.031 \\
\hline & $\sigma_{\mathrm{Si}}$ & 0.24 & 0.15 & 0.13 & 0.13 \\
\hline & $\sigma_{\mathrm{S}}$ & 0.011 & 0.008 & 0.004 & 0.004 \\
\hline CO utilisation rate, $\%$ & & 38 & 37 & 38 & 38 \\
\hline Coke rate, kg/tHM: & & 448 & 446 & 469 & 452 \\
\hline Productivity, t/24h: & & 1,680 & 1680 & 1509 & 1571 \\
\hline
\end{tabular}

${ }^{*}$ CFM $=$ Coal - Flue dust mixture

IS-furnace works, like blast furnace, on the counter current principle. Sintered zinc and lead concentrates, coke and additives like mill scale are charged at the top. At the bottom hot blast $\left(1,150^{\circ} \mathrm{C}\right)$ is injected. The liquid lead and slag are tapped at the bottom, the gaseous zinc leaves the furnace at the top. The iron containing components are removed with the slag.

Since 1998 residues from the iron and steel industry and non-ferrous industries are injected into the IS-furnace at M.I.M. Hüttenwerke Duisburg GmbH ${ }^{[11]}$.

Various mixtures from pulverised coal and iron, lead and zinc containing dusts were investigated in cooperation with M.I.M. for their use in the IS furnace $^{[12]}$. To characterise the dust samples the chemical composition, microstructure, mineral components, size distribution were determined and analysed. Table II and figures 3 and 4 show an example of some of these characteristics for EAF dust.

Volatilisation rates of 50-65\% for zinc and 45$55 \%$ for lead were achieved. This value for other dusts fluctuates in a wide range. For some dusts volatilisation of zinc rises with the $\mathrm{PC}$ rate in the mixture.

The grain size distribution is in the range between 0.2 and $30 \mu \mathrm{m}$ (Figs. 3 and 4). Some other dusts have a narrower range of size distribution range, e.g. 4-20 $\mu \mathrm{m}$ and build agglomerates which can cause problems when handling and injecting ${ }^{[7}$ and 13].
Table II. Composition of EAF dust, \%

Tabla II. Análisis químico del polvo del horno eléctrico de arco (HEA), \%

\begin{tabular}{ccccccc}
\hline $\mathrm{FeO}$ & $\mathrm{ZnO}$ & $\mathrm{Pb}$ & $\mathrm{C}$ & $\mathrm{CaO}$ & $\mathrm{K}_{2} \mathrm{O}$ & $\mathrm{Na}_{2} \mathrm{O}$ \\
\hline 33.32 & 32.56 & 1.69 & 1.61 & 5.70 & 1.60 & 1.70 \\
\hline
\end{tabular}

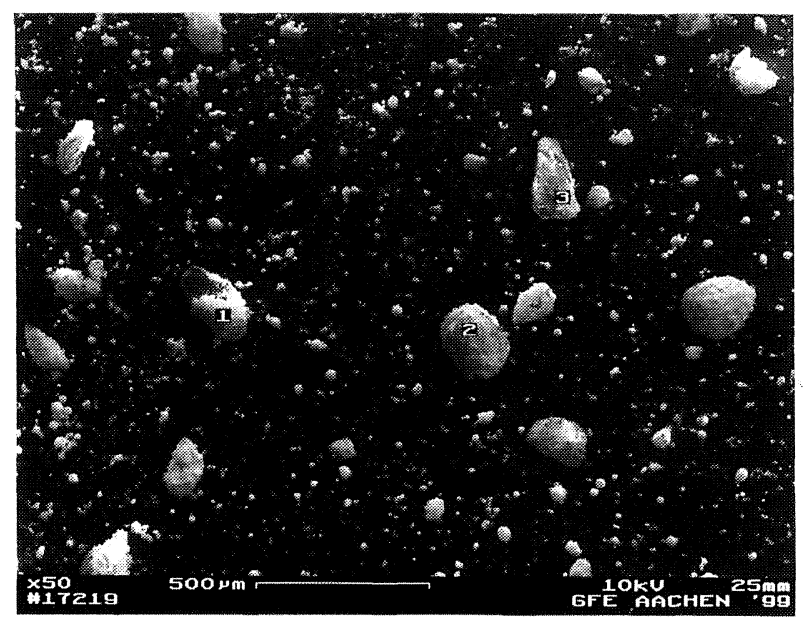

Figure 3. SEM picture of EAF dust ${ }^{[11]}$.

Figura 3. Foto SEM del polvo de HEA ${ }^{[11]}$.

Combustion degree of low volatile PC increases for $10 \%$ of EAF dust in the mixture (Fig. 5). Further increase in dust rate does not improve combustion efficiency of coal and moreover, can lead to its worsening (at $30 \%$ in the mixture). 


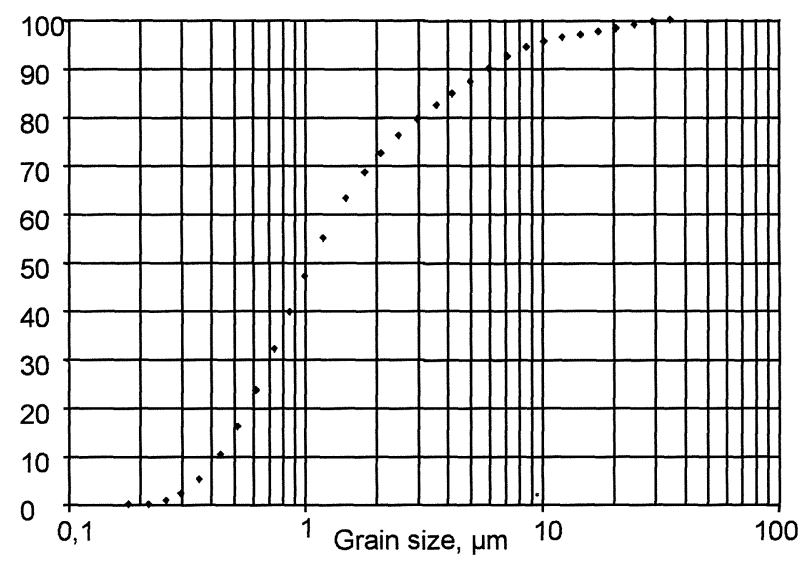

Figure 4. Size distribution of EAF dust ${ }^{[11]}$.

Figura 4. Distribución de tamaño de las partículas del polvo $H E A^{[11]}$.

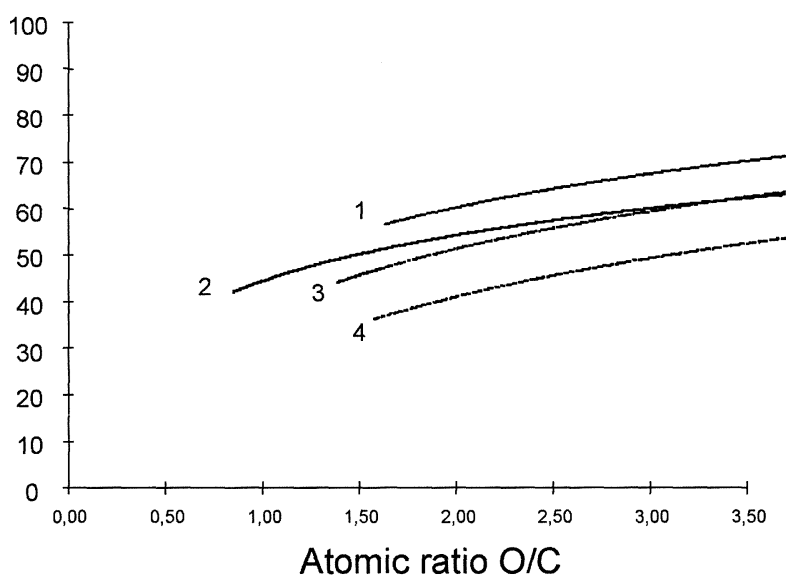

Figure 5. Combustion degree of PC with EAF dust: ${ }^{[11]}$

1: $10 \%$ EAF dust; 2: pure PC; 3: $20 \%$ EAF dust; $4: 30 \%$ EAF dust.

Figura 5. Grado de combustión del polvo de $H E A^{[11]}$ :

1: $10 \%$ pulvo HEA; 2: CP; 3: $20 \%$ pulvo HEA; $4: 30 \%$ pulvo HEA.

\section{CUPOLA AND OXICUP FURNACES}

Cupola furnace works also on the counter current principle and serves for smelting scrap and pig iron using coke. Gaseous $\left(\mathrm{CO}_{2}, \mathrm{SO}_{2}, \mathrm{NO}_{\mathrm{X}}\right)$ and solid (dusts) emissions are generated in the furnace and in subsequent foundry areas.

The possibility of injection of dry filter dusts into the cupola furnace without worsening the operation conditions and without increase of $\mathrm{FeO}$ content in slag has been shown in ${ }^{[14]}$. Nevertheless, injection of high rate of dust causes a drop in flame temperature at tuyeres and can also cause disturbance of furnace operation.
Use of natural gas / oxygen burners introduced into the tuyeres provides a drop in $\mathrm{CO}_{2}$ emission due to partial substitution of coke by natural gas and increase in the furnace productivity as well as rise of temperature potential ${ }^{[15]}$. Therefore higher rate of foundry and other iron containing dusts can be utilised. Presently Aachen University participates in the development and testing of natural gas/oxygen burner with simultaneous dust injection in order to adapt the cupola furnace process to the modern needs of economy and environment ${ }^{[16]}$.

A special shaft furnace -OxiCup- similar to the cupola furnace has been developed to recover residues of steel industry such as iron- and carbonrich dusts and sludges containing zinc, lead and alkali, as well as oil contaminated mill scale sludges, steel scrap, zinc coated scrap, and sponge iron (Fig. 6). The OxiCup plant at ThyssenKrupp Stahl produces hot metal from the mentioned iron bearing materials in the form of pellets or briquettes, or self-reducing pellets, using hot blast, coke and oxygen ${ }^{[17]}$.

Further development of OxiCup process targets recycling of in-plant fines like $\mathrm{BOF}$ and other $\mathrm{Fe}$, $\mathrm{Zn}, \mathrm{Pb}$ and alkali containing dusts by direct injection via the tuyeres (Fig. 6).

Aachen University is carrying out a metallurgical study on oxidation and smelting behaviour of real and artificially produced dusts using injection and smelting facilities ${ }^{[18]}$.

\section{CONCLUSIONS}

- Injection of fine residues in shaft furnaces provides direct recovery without preparation steps like agglomeration.

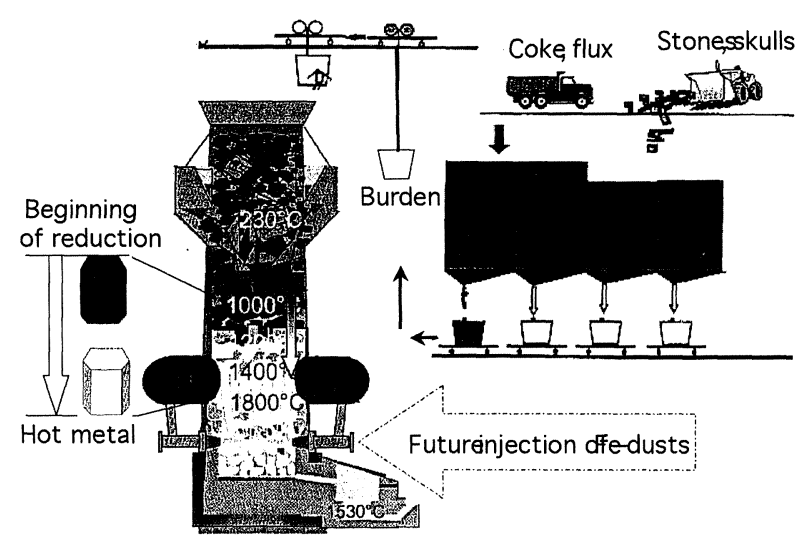

Figure 6. Scheme of OxiCup Process ${ }^{[15]}$.

Figura 6. Esquema del proceso OxiCup ${ }^{[15]}$. 
- Injection of flue dust in the mixture with PC into BF can provide increase in coal combustion degree and keep or increase furnace productivity and decrease coke rate.

- Injection of $\mathrm{Zn}, \mathrm{Pb}$ and alkali containing dusts into $\mathrm{BF}$ requires measures preventing the accumulation of these harmful elements or their compounds. Alternatively, such kind of residues can be injected into IS and OxiCup furnaces.

- Zn containing dusts increase PC combustion efficiency only at their low rate in the mixture $(10 \%)$. Small size and narrow range of size distribution of metallurgical dusts can cause their agglomeration and finally lead to problems during handling and injection.

- Use of natural gas/oxygen burner provides decrease in coke rate and $\mathrm{CO}_{2}$ emission as well as possibility of higher rate of iron containing dust injections.

- OxiCup process developed to recover residues of steel industry in the form of briquettes and pellets will be modernised to recycle these wastes also by injection.

\section{Acknowledgements}

The authors wish to acknowledge Donetsk Steel Plant, Ukraine for the organisation of industrial trials.

\section{REFERENCES}

[1] P.J. Koros, Proc. of Conf. Recycling and Waste Treatment in Mineral and Metal Processing, 16-20 June 2002, Luleå, Sweden, pp. 27-40.

[2] K. KNOP, Stahl Eisen, 122 (2002) 43-51.

[3] A. Babich, H.W. Gudenau, K. Mavrommatis, C. Froehling, A. Formoso, A. Cores and L. Garcia, Rev. Metal. Madrid 38 (2002) 288-305.
[4] H.W. Gudenau, D. SenK; K. Fukada, A. Babich, C. Froelhling, L.L. García, A. Formoso, FJ. Alguacil AND A. CoREs: Rev. Metal. Madrid 39 (2003) 367-377.

[5] A. Babich, H.W. Gudenau and D. SenK, Proc. $3^{\text {rd }}$ Int. Conf. Science and Technology of Ironmaking.(ICSTI) Düsseldorf, Alemania (2003) pp. 89-94.

[6] H.W. Gudenan, D. SenK, A. Babich, C. Fröhling, O.S. KWeOn, S. WANG AND T. Wieting, Rev. Metal. Madrid 41 (2005) 139-147.

[7] A. Babich, H.W. Gudenau, D. Senk, A. Formoso, J.L. Menéndez and V. Kochura, Proc. of Int. Blast Furnace Lower Zone Symp., 2002, Wollongong, Australia, pp. 16. 1-14.

[8] H. DENECKE, PhD Thesis, RWTH Aachen, 1999.

[9] H.W. Gudenau, A. Babich, H. DenecKe, S.L. JAROSHEVSKII AND V. KochurA, Stahl Eisen, 119 (12) (1999) 81-89.

[10] G. Carlsson, G. Berglund, E. Nilsson And F. SU. Proc. of Conf. Recycling and Waste Treatment in Mineral and Metal Processing, 2002, Luleå, Sweden, pp. 17-25.

[11] B. Schwab And W.D. Schneider, Proc. of Conf. Recycling and Waste Treatment in Mineral and Metal Processing, 2002, Luleå, Sweden, pp. 925-934.

[12] S. Geimer, PhD Thesis, RWTH Aachen, 2002.

[13] A. Babich, L. Garcia, J.L. Verduras, C. Cubillo, A. Formoso AND A. Cores, Rev. Metal. Madrid 38 (1998) 141-145.

[14] J.G. RACHNER, PhD Thesis, RWTH, Alemania, Aachen, 1995.

[15] T. Wieting, PhD Thesis, RWTH, Alemania, Aachen, 2005.

[16] G. STILL, Umweltschutz in der Stahlerzeugung, Lecture notes, RWTH, Aachen 2002.

[17] Melting of pig-iron with the OXI-Cupola, http://www. kuettner.de

[18] C. STEPHANY, PhD Thesis, RWTH Aachen, forthcoming. 